\title{
Urology education in the time of COVID-19
}

Maylynn Ding, $\mathrm{MD}^{1}$; Yuding Wang, $\mathrm{MD}^{1}$; Luis H. Braga, MD, MSc, $\mathrm{PhD}^{1,2}$; Edward D. Matsumoto, MD, MEd ${ }^{1}$

${ }^{1}$ McMaster University/Department of Surgery/Urology, Hamilton, ON, Canada; ${ }^{2}$ Clinical Urology Research Enterprise (CURE) Program, McMaster Children's Hospital, Hamilton, ON, Canada

Cite as: Can Urol Assoc J 2020 May 12; Epub ahead of print. http://dx.doi.org/10.5489/cuaj.6696

Published online May 12, 2020

We are living in unprecedented times. The emergence of coronavirus disease 2019 (COVID-19) and its rapid spread throughout the world has propelled the medical community into a time of accelerated innovation and change. Although the necessary focus has been on disease containment and delivery of care, the pandemic has had a profound impact on medical education at both the undergraduate and post-graduate levels.

Didactic and team-based teaching have long been integral to post-graduate education in any specialty, including urology $[1,2]$. Traditionally, these teaching sessions have taken place in physical spaces with "face to face" interactions. However, during the COVID-19 pandemic, social distancing has been adopted as a recommended preventative strategy pending development of an effective vaccine or treatment [3]. By definition, social distancing precludes residents and staff from gathering in lecture halls or classrooms. In response, many institutions have leveraged technology to adapt portions of curricula to online formats. This is enabled by the availability of user-friendly Voice over Internet Protocol (VoIP) software. Since the introduction of Skype, one of the first VoIP software with video chat, in 2003, the technology has matured and become more widespread [4]. There are now a variety of software with multi-video conferencing and screensharing capabilities. Some have end-to-end encryption. Many offer a free trial or free tier, with the option to upgrade for additional features. The availability of assessment technologies such as ExamSoft also enable administration of low-stakes tests from home.

Perhaps the most significant shift that has occurred in urology education during the COVID-19 pandemic is the rise of massive open online courses (MOOCs). MOOCs are openaccess, online courses aimed at unlimited participation [5,6]. They gained traction in 2012 with the emergence of well-funded course providers associated with top universities such as Coursera, Udacity, and EdX. Prior to the COVID-19 pandemic, MOOCs in urology are limited. Select professional organizations such as the American Urology Association and European Association 
of Urology offer online modules on a range of topics for members. Karolinksa Institute offers an introductory urology course via EdX and Johns Hopkins University offers a course on prostate cancer via Coursera $[7,8]$. However, these MOOCs are targeted to the general public and medical students. The COVID-19 pandemic saw the inception of a number of online lecture series targeted at urologists and urology trainees. Many are developed by a global network of collaborating institutions. This is likely spurred by a renewed interest in leveraging technology for online learning combined with a shared desire to continuing urology education during a time of crisis. Table 1 summarizes some of the ongoing MOOCs in urology at the time of this writing. They are all open-access and given by experts in their respective fields. Many include case-based discussions and Q\&A sessions and are recorded for participants who are unable to attend the live stream. It is our hope that these initiatives are the first of many that will continue after the pandemic. Perhaps we will see further enhancements, such as the incorporation of forums or social media discussions to support ongoing learner and educator interaction after the live lectures.

In many urology residency programs around Canada, traditional didactic teaching sessions including urology school, journal clubs and urology grand rounds are now facilitated via an online platform. Locally, at McMaster, the surgical foundations program, which encompasses the first two years of Canadian surgical residency training, transitioned all lectures to Zoom, making use of the chat function for Q\&A and attendance purposes. This pivot to online curricula and de-centralization also empower resident-led education initiatives. Residents have the same easy access to VoIP software as staff and administrators. Here at McMaster, weekly urology school sessions and chief rounds have been conducted via Zoom. Adaptation to online teaching was quick and seamless for both the lecturers and residents. The ease of the transition has also led to new educational initiatives at McMaster such as the biweekly urology chief lecture series for junior residents on key foundational topics in urology. Online curricula are low-cost to implement. They are free of the many logistical barriers associated with organizing traditional face-to-face teaching sessions. These barriers are especially true for the aggregate teaching faculty, which has traditionally been less available to contribute with teaching sessions from their community hospitals due to the increased amount of time required for such activities. By using platforms like Zoom, they can substantially cut down on travel time and parking, making these teaching initiatives more feasible. Another advantage is that RPC meetings can take place with full participation of all members, as displacement from one hospital to another is no longer an issue.

The COVID-19 pandemic has transformed the landscape of medical education around the world, forcing institutions to adapt and evolve. Technology has played a key role, allowing the proliferation of online curricula and MOOCs. There is potential for technology to address other educational shortfalls. Simulation training, for example, may help mediate the unanticipated decrease in resident operative exposure brought about by hospital restriction of elective urological surgeries. Although many of the urology MOOCs began as COVID-19 pandemic 
initiatives, their implications are far-reaching. The ability of MOOCs to transcend institutional, geographic, and temporal boundaries is a unique strength. They not only make high-quality urology education accessible to anyone with a reliable Internet connection, they have also become foci of international collaboration and conversation. The value of these MOOCs postpandemic should not be overlooked. 


\section{References}

1. Skinner TAA, Ho L, Touma NJ. Study habits of Canadian urology residents: Implications for development of a competence by design curriculum. Can Urol Assoc J. 2017;11(34):83-7.

2. Daniels K, Arafeh J, Clark A, et al. Prospective Randomized Trial of Simulation Versus Didactic Teaching for Obstetrical Emergencies. Simulation in Healthcare. 2010 Feb;5(1):40-45.

3. Rio C del, Malani PN. 2019 Novel Coronavirus-Important Information for Clinicians. JAMA. 2020 Mar 17;323(11):1039-40.

4. Garfinkel S. VoIP and Skype security. Skype Security Overview-Rev 1.6. 2005. From http://www.tacticaltech.org/files/tacticaltech/Skype_Security.pdf. (Accessed April 28, 2020)

5. Chen BY, Kern DE, Kearns RM, et al. From Modules to MOOCs: Application of the SixStep Approach to Online Curriculum Development for Medical Education. Acad Med. 2019;94(5):678-85.

6. Pickering JD, Henningsohn L, DeRuiter MC, et al. Twelve tips for developing and delivering a massive open online course in medical education. Medical Teacher. $2017 \mathrm{Jul}$ 3;39(7):691-6.

7. KIUrologyX: Urology As You Like It-A Massive Open Online Course for Medical Students, Professionals, Patients, and Laypeople A like. Henningsohn, Lars et al. European Urology, Volume 72, Issue 3, 321 - 322

8. Understanding Prostate Cancer [Internet]. Coursera. From: https://www.coursera.org/learn/prostate-cancer. (Accessed Apr 28, 2020 
Figure and Tables

\begin{tabular}{|c|c|c|c|c|c|}
\hline Name & Audience & Content & Schedule & \begin{tabular}{|l} 
Recorded \\
$(\mathbf{Y} / \mathbf{N})$
\end{tabular} & Website \\
\hline $\begin{array}{l}\text { Educational Multi- } \\
\text { institutional Program } \\
\text { for Instructing } \\
\text { Residents (EMPIRE) } \\
\text { Lecture Series }\end{array}$ & $\begin{array}{l}\text { Urology } \\
\text { residents }\end{array}$ & Varied topics & $\begin{array}{l}\text { Monday to Friday } \\
\text { 7:00-9:00am EST } \\
\text { (2 lectures a day) }\end{array}$ & $\mathrm{Y}$ & https://nyaua.com/empire/ \\
\hline $\begin{array}{l}\text { University of } \\
\text { Southern California } \\
\text { 'Masters of Urology' } \\
\text { Zoom Clinical Series }\end{array}$ & $\begin{array}{l}\text { Residents } \\
\text { And } \\
\text { practicing } \\
\text { urologists }\end{array}$ & $\begin{array}{l}\text { Varied topics } \\
\text { (panel } \\
\text { discussions) }\end{array}$ & $\begin{array}{l}\text { Thursday 12:30- } \\
\text { 2:00pm EST }\end{array}$ & $\mathrm{N}$ & $\begin{array}{l}\text { https://usc.zoom.us/webinar/ } \\
\text { register/WN_a1qzM5ppSD- } \\
\text { cxmDoggKLxA }\end{array}$ \\
\hline $\begin{array}{l}\text { Urology Collaborative } \\
\text { Online Virtual } \\
\text { Didactics (COViD) } \\
\text { Lecture Series }\end{array}$ & $\begin{array}{l}\text { Urology } \\
\text { residents }\end{array}$ & Varied topics & $\begin{array}{l}\text { Monday to Friday } \\
\text { 12:00-2:00pm EST } \\
\text { (2 lectures a day) }\end{array}$ & Y & $\begin{array}{l}\text { https://urologycovid.ucsf.ed } \\
\text { u/ }\end{array}$ \\
\hline $\begin{array}{l}\text { Pediatric Urology } \\
\text { Fellowship Lectures } \\
\text { Online (PedsUroFLO) }\end{array}$ & $\begin{array}{l}\text { Urology } \\
\text { residents } \\
\text { and fellows }\end{array}$ & $\begin{array}{l}\text { Pediatric } \\
\text { urology }\end{array}$ & $\begin{array}{l}\text { Tuesday to } \\
\text { Thursday }(7: 00- \\
\text { 8:00pm EST) }\end{array}$ & $\mathrm{Y}$ & https://pedsuroflo.ucsf.edu/ \\
\hline $\begin{array}{l}\text { Genitourinary } \\
\text { Reconstruction } \\
\text { Lecture Series }\end{array}$ & $\begin{array}{l}\text { Urology } \\
\text { residents } \\
\text { and fellows }\end{array}$ & $\begin{array}{l}\text { Reconstructiv } \\
\text { e urology }\end{array}$ & $\begin{array}{l}\text { Wednesday - } \\
\text { Friday (9:00- } \\
\text { 10:00am EST) }\end{array}$ & $\mathrm{Y}$ & $\begin{array}{l}\text { https://zoom.us/webinar/regi } \\
\text { ster/WN_sZ1uW2Z- } \\
\text { TmqGLvZRGtm1wg }\end{array}$ \\
\hline $\begin{array}{l}\text { Urology Teaching } \\
\text { Collaborative }\end{array}$ & $\begin{array}{l}\text { Urology } \\
\text { residents }\end{array}$ & Varied topics & $\begin{array}{l}\text { Monday - } \\
\text { Thursday (4:00- } \\
\text { 5:00pm EST) }\end{array}$ & $\mathrm{N}$ & $\begin{array}{l}\text { Email for access: } \\
\text { urocme@amc.edu }\end{array}$ \\
\hline
\end{tabular}

